\title{
Extracellular peptidase and carbohydrate hydrolase activities in an Arctic fjord (Smeerenburgfjord, Svalbard)
}

\author{
Andrew D. Steen ${ }^{1,3, *}$, Carol Arnosti ${ }^{2}$ \\ ${ }^{1}$ Center for Geomicrobiology, Aarhus University, 8000 Aarhus C, Denmark \\ ${ }^{2}$ Department of Marine Sciences, University of North Carolina at Chapel Hill, Chapel Hill, North Carolina 27599, USA \\ ${ }^{3}$ Present address: Department of Microbiology, University of Tennessee, Knoxville, Tennessee 37996, USA
}

\begin{abstract}
Measurements of the spectrum of extracellular enzymes present in an environment can indicate the nature of organic substrates available to microorganisms. We report the activities in an Arctic fjord (Smeerenburgfjord, Svalbard) of the extracellular carbohydrate hydrolases $\alpha$-galactosidase, $\beta$-glucosidase, and chitobiase, and the extracellular peptidases leucyl aminopeptidase, trypsin, and chymotrypsin. Among the carbohydrate hydrolases, $\beta$-glucosidase had the highest potential activity. Although extracellular leucyl aminopeptidase is frequently assayed in marine systems, activities of other peptidases have only rarely been reported. Peptidase activities were higher than carbohydrate hydrolase activities by approximately 2 orders of magnitude. Activities of leucyl aminopeptidase (an exopeptidase which cleaves terminal residues from a protein) were higher than trypsin and chymotrypsin (both endopeptidases which cleave interior bonds). In contrast to previous measurements from coastal, temperate environments, potential activity of leucyl aminopeptidase in Smeerenburg was higher than that of the endopeptidases trypsin and of chymotrypsin. These results suggest that leucyl aminopeptidase may not always be a reliable proxy for the total peptidolytic potential of microbial communities.
\end{abstract}

KEY WORDS: Extracellular enzymes $\cdot$ Microbial loop $\cdot$ Proteinase $\cdot$ Beta-glucosidase $\cdot$ Chitinase

\section{INTRODUCTION}

Heterotrophic microorganisms must use extracellular enzymes to hydrolyze macromolecules outside of the cell prior to uptake, because only small molecules $(<\sim 600 \mathrm{Da})$ can be transported across the cell membrane by general uptake porins (Benz \& Bauer 1988). The types and rates of enzyme activities in an environment may therefore serve as an indicator of the macromolecules potentially available to the microbial community (Sinsabaugh et al. 2009).

We investigated the activities of 6 classes of extracellular enzymes hydrolyzing peptides and carbohydrates in the surface and bottom waters of an Arctic fjord: Smeerenburgfjord, Svalbard. We assayed potential activities of 3 classes of peptidases (leucyl aminopeptidase, an exopeptidase preferentially hydrolyzing terminal leucine residues; trypsin and chymotrypsin, 2 endopeptidases which hydrolyze internal peptide bonds) as well as 3 exo-acting carbohydrate hydrolases $(\alpha$-galactosidase, $\beta$-glucosidase, and chitobiase, each of which hydrolyze terminal sugars). Bacterial production (by the leucine incorporation method) and cell abundance were also measured.

Based on previous investigations documenting significant differences in activities of a suite of closely related polysaccharide hydrolases in temperate and in Arctic pelagic environments (Arnosti et al. 2005, 2011, Teske et al. 2011), we sought to investigate whether patterns of peptidase activity in Arctic waters also differ from those in temperate locations. 
Peptidase activity in seawater is most frequently measured using a single substrate analog, L-leucine7-amido-4-methylcoumarin (leu-MCA). Leu-MCA reports the activity of leucyl aminopeptidase (Enzyme Commission [EC] no. 3.4.11.1). Leucyl aminopeptidase, however, represents only a small fraction of the total diversity of peptidases, which include 6 major families, each of which has a different active site and mechanism (Dixon \& Webb 1979). Several studies have used fluorescently labeled peptides and chromatographic separation of hydrolysis products to demonstrate that the position of specific residues can influence peptide hydrolysis rates (Pantoja et al. 1997, 2009, Pantoja \& Lee 1999, Liu et al. 2010). Only a handful of studies, all from temperate coastal environments, have used methylcoumarin (MCA)-type fluorogenic substrate analogs to report activities of peptidases other than leucyl aminopeptidase (Obayashi \& Suzuki 2005, 2008a,b, Bong et al. 2009, Obayashi et al. 2010); these studies demonstrated considerable differences in hydrolysis rates for different classes of peptidases. Possible differences in hydrolysis rates of different classes of peptidases in high-latitude waters, to the best of our knowledge, had not previously been investigated.

\section{MATERIALS AND METHODS}

Surface $(0.5 \mathrm{~m})$ and bottom water $(200 \mathrm{~m})$ were collected by Niskin bottle at Smeerenburgfjord, Svalbard, Stn J (79² $42.808^{\prime} N, 1^{\circ} 05.200^{\prime} E_{i}$ total water depth: $212 \mathrm{~m}$ ) on 5 September 2010. Smeerenburgfjord is influenced by water from the West Spitzbergen Current (Aagaard et al. 1987) and by meltwater from the glaciers that surround it, but oceanographic conditions there have not been studied in detail. Surface and bottom water temperatures and salinity were $2.8^{\circ} \mathrm{C}$ and 32 , and $1^{\circ} \mathrm{C}$ and 33, respectively, as measured by hand-held thermometer and refractometer. Water samples were stored at in situ temperature in polycarbonate cubitainers under daylight (surface water) or in the dark (bottom water) for the transit (ca. $24 \mathrm{~h}$ ) to the shore-based laboratory in Ny Allesund, Svalbard, by placing the samples in large coolers filled with water from the relevant depth. Previous work indicated that enzyme activities are stable during this interval (Steen \& Arnosti 2011, Baltar et al. 2013). All further work was performed in a temperature-controlled chamber at $4^{\circ} \mathrm{C}$.

Cells were counted by microscopy after DAPI staining (Porter \& Feig 1980). Leucine incorporation was measured using ${ }^{3} \mathrm{H}$-leucine $\left(144.2 \mathrm{kCi} \mathrm{mol}^{-1}\right)$ and the microcentrifuge tube method (Kirchman 1993). ${ }^{3} \mathrm{H}$-leucine was added to a final concentration of $10 \mathrm{nM}$ in triplicate samples plus 1 killed control (5\% trichloroacetic acid) and incubated for approximately $1 \mathrm{~h}$. Rates measured using $20 \mathrm{nM}{ }^{3} \mathrm{H}$-leucine were not detectably higher than the rates using $10 \mathrm{nM}$ leucine, indicating that $10 \mathrm{nM}$ leucine was saturating.

Enzyme activities were measured using the methylumbelliferyl (MUF)- or MCA-linked substrates listed in Table 1. Fluorogenic substrates were dissolved in a solution of $50 \%$ artificial seawater $(\mathrm{pH} 8.2$, salinity 35) and $50 \%$ dimethylsulfoxide for a stock concentration of $10 \mathrm{mM}$. Each substrate was added to triplicate $3.5 \mathrm{ml}$ seawater samples for a final substrate concentration of $100 \mu \mathrm{M}$. Killed controls consisted of seawater that was autoclaved prior to substrate addition. Timepoints were taken immediately after addition of the substrate and then after approximately 3 and $15 \mathrm{~h}$. Hydrolysis rates were calculated using precise incubation times. At each timepoint, a $1 \mathrm{ml}$ seawater sample was removed and mixed in a $4 \mathrm{ml}$ cuvette with $1 \mathrm{ml}$ sodium borate buffer (10 mM, pH 10). Fluorescence was measured immediately using a Turner Biosystems TBS-380 solid-state fluorimeter using the 'UV' channel (excitation: $365 \mathrm{~nm}$; emission: 440 to $470 \mathrm{~nm}$ ). Instrument drift was monitored using a Turner Biosystems fluorescent solid standard, but because the variation in solid standard was small and no systematic drift was observed, the raw data were not normalized by the fluorescence of the solid stan-

Table 1. Enzymes and substrates used in the present study. MCA: methyl-coumarin; MUF: methylumbelliferyl; Boc: tert-Butyloxycarbonyl

\begin{tabular}{|llc|}
\hline Enzyme & Substrate & $\begin{array}{c}\text { Sigma-Aldrich } \\
\text { product no. }\end{array}$ \\
\hline$\alpha$-galactosidase & 4-MUF $\alpha$-galactopyranoside & M7633 \\
$\beta$-glucosidase & 4-MUF $\beta$-glucopyranoside & M3633 \\
Chitobiase & 4-MUF $\beta$-D-N,N -diacetylchitobioside & M9763 \\
Leucyl aminopeptidase & L-leucine-7-amido-4-MCA & L2145 \\
Chymotrypsin(1) & Ala-ala-phe-7-amido-4-MCA & A3401 \\
Chymotrypsin(2) & N-succinyl-ala-ala-pro-phe-7- & S9761 \\
& amido-4-MCA & B6388 \\
Trypsin(1) & Boc-phe-ser-arg-7-amido-4-MCA & B4153 \\
Trypsin(2) & Boc-gln-ala-arg-7-amido-4-MCA & \\
\hline
\end{tabular}


dard. In a separate experiment, performed $3 \mathrm{~d}$ after initial water collection, saturation curves were measured for each substrate in surface water. Values of the Michaelis constant $K_{\mathrm{m}}$ were determined using nonlinear least-squares fitting implemented using the R statistical package ( $R$ Development Core Team 2012). Based on variation in slopes among killed controls and the slope of the respective calibration curves for MUF and MCA, the limit of detection for carbohydrate hydrolases was estimated to be $0.05 \mathrm{nM} \mathrm{l}^{-1} \mathrm{~h}^{-1}$ for carbohydrate hydrolases and $2.6 \mathrm{nM} \mathrm{l}^{-1} \mathrm{~h}^{-1}$ for peptidases (although the limits of quantification were higher because much of the variation among replicates was apparently due to biological variation rather than analytical error).

Enzymes are defined by the reactions they catalyze. Fluorogenic substrates are designed to measure the activity of individual enzyme classes with minimal interference from non-targeted enzymes. However, due to the broad and variable specificity of peptidases (Dixon \& Webb 1979) and the complex mixture of enzymes active in seawater (Arrieta \& Herndl 2002), the hydrolysis of any substrate represents the action of the target enzyme plus possible contributions from an unquantified number of other enzyme classes. With these caveats in mind, for simplicity, we refer to the hydrolysis rates of the fluorogenic substrates as measurements of the activity of the enzymes listed in Table 1.

\section{RESULTS AND DISCUSSION}

The rate of substrate hydrolysis over time was approximately constant during the $\sim 16 \mathrm{~h}$ incubations (with the exception of 1 replicate of $\alpha$-galactosidase in bottom water), indicating that the relatively long incubations used here were an appropriate way to optimize detection limits of enzyme activities (Fig. 1). Peptidase potential activities were considerably higher than carbohydrate hydrolase potential activities, which were below detection limits in all but 1 case (Fig. 2). All detectable activities were higher in surface water than in bottom water. Among the carbohydrate hydrolase activities, only $\beta$-glucosidase in surface water was significantly greater than zero (Student's $t$-test, Bonferroni-Holm-adjusted $\mathrm{p}<0.05$, $\mathrm{n}=3$ per substrate and site). All peptidase substrates were detectably hydrolyzed in surface and bottom water, with the exception of chymotrypsin(1) (alaala-phe-MCA) in bottom water (Fig. 2b). Both bulk and cell-specific leucine incorporation were higher in surface water than in bottom water (Table 2).

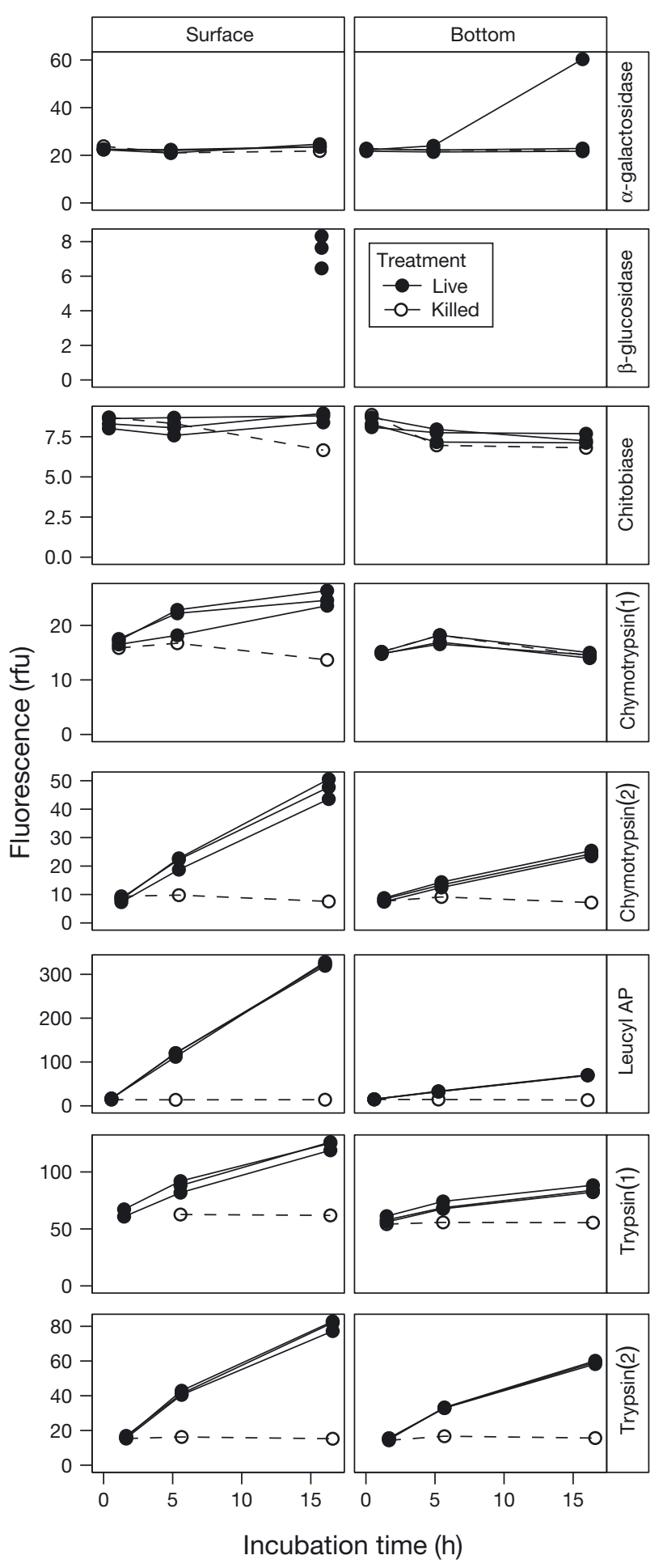

Fig. 1. Fluorescence as a function of time. The roughly linear relationship between fluorescence and time (with the exception of 1 replicate of $\alpha$-galactosidase) indicates that activities were roughly constant over the $16 \mathrm{~h}$ incubation period. Values below the instrument detection limit of -0.011 relative fluorescence units (rfu), including all measurements of $\beta$-glucosidase in bottom water, are not plotted. Leucyl AP: leucyl aminopeptidase 


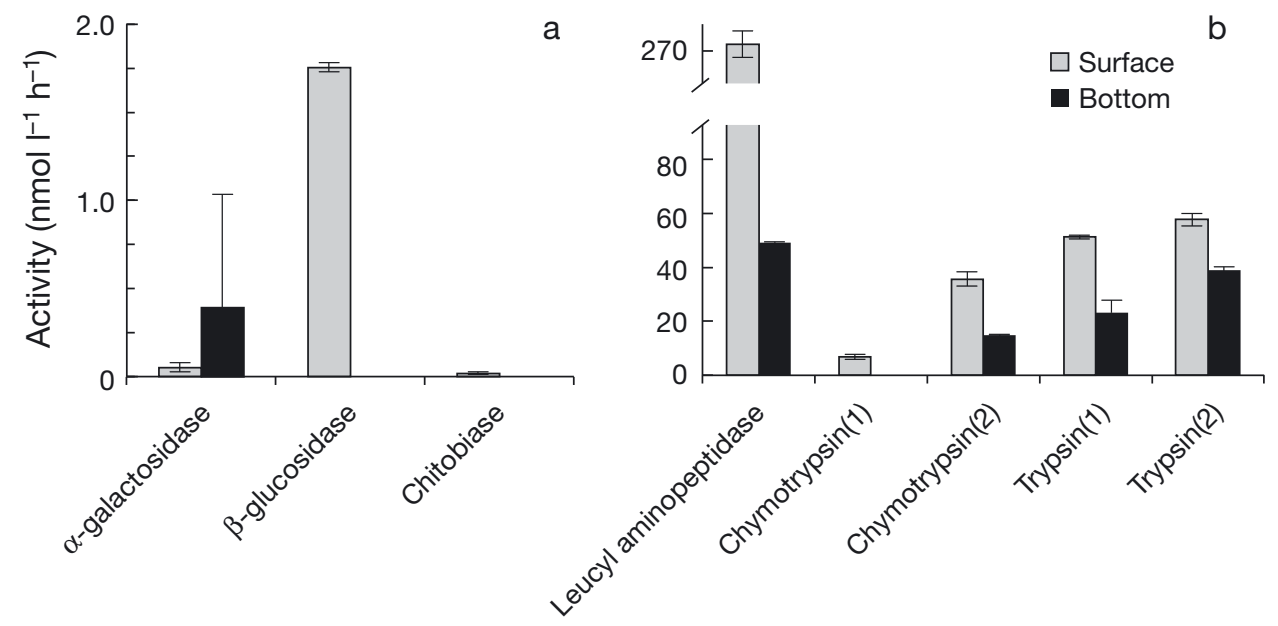

Fig. 2. Activities of (a) carbohydrate hydrolases and (b) peptide hydrolases. Error bars represent SD of 3 replicates. Note that the 2 panels have differently scaled axes

Table 2. Microbial cell counts $\left(\mathrm{l}^{-1}\right)$, bacterial production (pmol leu $\mathrm{l}^{-1} \mathrm{~h}^{-1}$ ), cell-specific bacterial production (amol leu cell $^{-1} \mathrm{~h}^{-1}$ ), and cell-specific enzyme activities (amol MUF or MCA cell ${ }^{-1} \mathrm{~h}^{-1}$, where MUF is methylumbelliferyl, MCA is methylcoumarin) in surface $(0.5 \mathrm{~m})$ and bottom $(200 \mathrm{~m})$ waters. The error term indicates SD of 3 replicates. ns: not significantly greater than zero

\begin{tabular}{|lcc|}
\hline & \multicolumn{2}{c|}{ Water depth } \\
& $0.5 \mathrm{~m}$ & $200 \mathrm{~m}$ \\
\hline Cell count & $5.6 \times 10^{8}$ & $1.7 \times 10^{8}$ \\
Bulk bacterial production & $78.9 \pm 3.0$ & $7.34 \pm 0.33$ \\
Cell-specific bacterial production & 0.14 & 0.043 \\
$\alpha$-galactosidase & $\mathrm{ns}$ & $\mathrm{ns}$ \\
$\beta$-glucosidase & $3.15 \pm 0.05$ & $\mathrm{~ns}$ \\
Chitobiase & $\mathrm{ns}$ & $\mathrm{ns}$ \\
Leucyl aminopeptidase & $490 \pm 8.9$ & $289 \pm 0.9$ \\
Chymotrypsin(1) & $12.2 \pm 1.6$ & $\mathrm{~ns}$ \\
Chymotrypsin(2) & $64.0 \pm 4.5$ & $87 \pm 0.6$ \\
Trypsin(1) & $91.9 \pm 1.2$ & $137 \pm 8.1$ \\
Trypsin(2) & $104 \pm 4.3$ & $230 \pm 2.1$ \\
\hline
\end{tabular}

Hydrolysis rates for MUF- $\beta$-glucose in surface waters $\left(1.8 \mathrm{nmol} \mathrm{l}^{-1} \mathrm{~h}^{-1}\right)$ were within the range ( 1 to 9 nmol monomer $\mathrm{l}^{-1} \mathrm{~h}^{-1}$ ) reported by Arnosti (2008) and Teske et al. (2011) for hydrolysis of a series of polysaccharides and plankton substrates in surface as well as bottom waters of Smeerenburgfjord. In those previous investigations, however, 3 of the 10 polysaccharide/plankton substrates remained unhydrolyzed in surface and bottom water samples, even after extended incubation. In the present study, 2 of the 3 carbohydrate-containing substrates were not hydrolyzed in surface waters, and none were hydrolyzed in bottom waters, over the $\sim 16 \mathrm{~h}$ incubation period, demonstrating comparatively low bioavailability of some types of carbohydratecontaining compounds in situ as well as during long-term incubations.
Only $K_{\mathrm{m}}$ values for leucyl aminopeptidase (139 \pm $70 \mu \mathrm{M})$, chymotrypsin(2) (176 $\pm 70 \mu \mathrm{M})$, and tryp$\sin (2)(50 \pm 22 \mu \mathrm{M})$ could be determined from nonlinear least-squares fitting ( $p<0.05 ;$ Fig. 3$)$. These values indicate that the chosen value of $100 \mu \mathrm{M}$ for $V_{\max }$ (maximum hydrolysis rate) measurements was less than saturating. When potential activity $V$ is measured at a less-than-saturating substrate concentration $[s], V_{\max }$ can be calculated as:

$$
V_{\max }=V \times\left(K_{\mathrm{m}}+[s]\right) /[s]
$$

Since [s] was $100 \mu \mathrm{M}$, activities measured here underestimate $V_{\max }$ by factors of 1.5 to 2.8 .

The $K_{\mathrm{m}}$ values reported here are considerably higher than the $16 \mu \mathrm{M}$ reported for trypsin-like peptidases reported by Obayashi \& Suzuki (2005), which were measured using boc-phe-ser-arg-MCA (tryp$\sin (1)$ in the present study; our Table 1) at $25^{\circ} \mathrm{C}$. The differences in $K_{\mathrm{m}}$ are consistent with psychrophily, in that psychrophilic enzymes often (but not always) exhibit higher $K_{\mathrm{m}}$ values than mesophilic enzymes due to weak binding at the active site that results from the increased structural flexibility common in psychrophilic enzymes (Feller \& Gerday 2003). Higher $K_{\mathrm{m}}$ values have been reported elsewhere in cold seawater samples: $K_{\mathrm{m}}$ values for leucyl aminopeptidase were reported as $\sim 100 \mu \mathrm{M}$ in the Arctic Ocean at $-1^{\circ} \mathrm{C}$ (Huston \& Deming 2002) and $130 \mu \mathrm{M}$ in the Beaufort Sea at $-1^{\circ} \mathrm{C}$ (Kellogg et al. 2011). Higher $K_{\mathrm{m}}$ values for peptidases in cold water may be the reason that heterotrophic bacteria require higher substrate concentrations at colder temperatures (Pomeroy \& Wiebe 2001).

Among peptidases, substrate preferences were evident. Chymotrypsin activity was higher when measured by N-succinyl-ala-ala-pro-phe-MCA (chymotrypsin(2)) than ala-ala-phe-MCA (chymotrypsin(1)), 
and trypsin activity was higher when measured by boc-gln-ala-arg-MCA (trypsin(2)) than by boc-pheser-arg-MCA (trypsin(1); Fig. 2b). Regardless of the specific substrate, trypsin activity was higher than chymotrypsin activity, and detected activities were

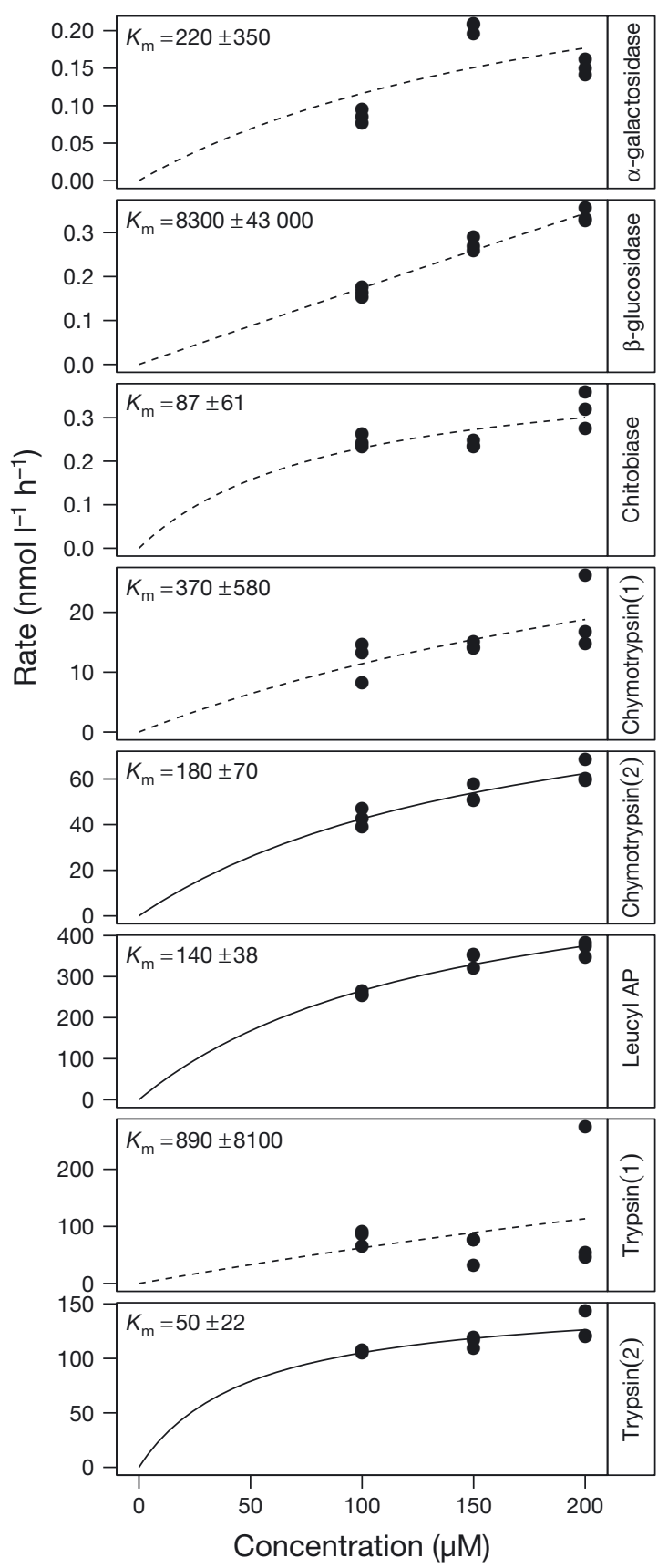

Fig. 3. Saturation curves for each substrate. Solid lines indicate fits to a Michaelis-Menten kinetic model. Dashed lines indicate $K_{\mathrm{m}}$ values not significantly distinguishable from zero. Note differing scales on $y$-axis between panels. Leucyl AP: leucyl aminopeptidase higher in surface water than in bottom water (Fig. 2b). In all cases, leucyl aminopeptidase activities were considerably greater than trypsin or chymotrypsin activities (Table 2).

With few exceptions, studies investigating peptidase in seawater report only leucyl aminopeptidase activities. Obayashi \& Suzuki (2005), however, explicitly compared the activities of endo- and exo-acting peptidases in coastal southern Japanese waters, testing activities with 16 different MCA-labeled substrates. They found that trypsin and chymotrypsin activities were greater by a factor of 2 to 8 than aminopeptidases in all of their samples (with the exception of the 2 smallest trypsin substrates, which showed activity comparable to that of aminopeptidases). Subsequent work at the same location and in coastal California (Obayashi \& Suzuki 2008a, Bong et al. 2009, Obayashi et al. 2010) also showed consistently higher trypsin and chymotrypsin than leucyl aminopeptidase activities in unfiltered, freshly sampled seawater. That pattern contrasts strongly with the high leucyl aminopeptidase relative to trypsin and chymotrypsin activity observed here. The facts that potential activities were measured at somewhat below saturating values, and that $K_{\mathrm{m}}$ values varied somewhat among the peptidases for which $K_{\mathrm{m}}$ was measurable, do not influence the conclusion that potential leucyl aminopeptidase activities were high relative to potential activities of trypsin and chymotrypsin (Table 3).

$V_{\max }$ of leu-MCA hydrolysis has sometimes been used in models as the maximum total rate of protein hydrolysis (Hoppe et al. 2002, Kellogg et al. 2011). More often, leucyl aminopeptidase activity has been

Table 3. Activities and activity ratios of peptidases in coastal Japan and Smeerenburgfjord, measured using the same substrates (see Table 1). Enzyme activities are in units of $\mathrm{nmol}^{-1} \mathrm{~h}^{-1}$; activity ratios are dimensionless. Values in parentheses are ratios of $V_{\max }$ calculated from observed $v$ and measured $K_{\mathrm{m}}$ as described in the 'Discussion'

\begin{tabular}{|c|c|c|c|c|}
\hline & $\begin{array}{l}\text { Coastal } \\
\text { Japan }^{\mathrm{a}}\end{array}$ & $\begin{array}{l}\text { Coastal } \\
\text { Japan }^{b}\end{array}$ & $\begin{array}{l}\text { Smeeren- } \\
\text { burgfjord, } \\
\text { surface }^{\mathrm{c}}\end{array}$ & $\begin{array}{l}\text { Smeeren- } \\
\text { burgfjord, } \\
\text { bottom }^{\mathrm{c}}\end{array}$ \\
\hline Leucyl aminopeptidase & 35 & 30 & 273 & 49 \\
\hline Trypsin(1) & 184 & 228 & 51 & 23 \\
\hline Chymotrypsin(2) & 42 & 75 & 36 & 15 \\
\hline $\begin{array}{l}\text { Leucyl aminopeptidase: } \\
\text { trypsin(1) }\end{array}$ & 0.14 & 0.13 & 5.3 & 2.1 \\
\hline $\begin{array}{l}\text { Leucyl aminopeptidase: } \\
\text { chymotrypsin(2) }\end{array}$ & 0.62 & 0.40 & $7.7(6.6)$ & $3.3(2.9)$ \\
\hline \multicolumn{5}{|c|}{$\begin{array}{l}\text { a Data read from plots in Obayashi \& Suzuki (2005) } \\
{ }^{b} \text { Data read from plots in Obayashi \& Suzuki }(2008 b) \\
\text { cPresent study }\end{array}$} \\
\hline
\end{tabular}


used implicitly or explicitly as a representative proxy for the total pool of proteolytic enzymes (e.g. Hoppe et al. 1988, Smith et al. 1992, Zaccone et al. 2012). Similarly, ratios of $\beta$-glucosidase:leucyl aminopeptidase activities, based on hydrolysis of MUF- $\beta$-glu and leu-MCA, have been used as indicators of the relative preference of microbial communities for carbon-rich versus nitrogen-rich substrates (e.g. Christian \& Karl 1995, Sinsabaugh et al. 2009). The results presented here, combined with peptidase studies using fluorogenic substrates in coastal, temperate environments (Obayashi \& Suzuki 2005, 2008a,b, Bong et al. 2009, Obayashi et al. 2010) and studies using a suite of oligopeptides (Pantoja \& Lee 1999, Liu et al. 2010), demonstrate that pelagic communities can express distinct patterns of extracellular peptidases, and that leucyl aminopeptidase contributes a variable amount to total peptidolytic potential.

The range in aminopeptidase:endopeptidase activity ratios - i.e. the ratio observed in the present study divided by the ratio observed by Obayashi \& Suzuki (2005, 2008a,b), Bong et al. (2009) and Obayashi et al. (2010) — varies between 8.3 and 41 , or 0.9 to 1.6 orders of magnitude, depending on which sites and specific substrates are compared. Observed leucyl aminopeptidase: $\beta$-glucosidase activity ratios in seawater range over 4 orders of magnitude, from 0.13 at the equator to $>1000$ near the poles (Christian \& Karl 1995, Huston \& Deming 2002). At the global scale, therefore, the variable contribution of leucyl aminopeptidase to total peptidase activity may not be the most important factor determining the ratios of aminopeptidase to other enzymes. In an individual sample, however, assays of leucyl aminopeptidase may capture most peptidolytic potential activity (as in Smeerenburgfjord at the time of sampling) or may miss the vast majority of it (as in Obayashi \& Suzuki 2005, 2008a,b, Obayashi et al. 2010). Further investigation of the range of peptidases active in diverse marine environments will provide greater insight into the types of enzymes that microbial communities use to access protein in seawater, and why some dominate over others in specific settings or under specific conditions.

Acknowledgements. We thank Captain Stig Henningsen and first mate Oskar Ström of the MV 'Farm', the employees of KingsBay in Ny Ålesund, and the shipboard scientific party for a successful field trip. Funding for the fieldwork was provided by the Max Planck Institute for Marine Microbiology. Funding for A.D.S. was provided by the Max Planck Society and the Danish National Research Foundation. Funding for C.A. was provided by the Max Planck Society and National Science Foundation (NSF) grant OCE0848703 .

\section{LITERATURE CITED}

Aagaard K, Foldvik A, Hillman SR (1987) The West Spitsbergen Current: disposition and water mass transformation. J Geophys Res 92:3778-3784, doi:10.1029/JC092iC04p03778

Arnosti C (2008). Functional differences between Arctic seawater and sedimentary microbial communities: contrasts in microbial hydrolysis of complex substrates. FEMS Microbiol Ecol 66:343-351

Arnosti C, Durkin S, Jeffrey WH (2005) Patterns of extracellular enzyme activities among pelagic marine microbial communities: implications for cycling of dissolved organic carbon. Aquat Microb Ecol 38:135-145

Arnosti C, Steen AD, Ziervogel K, Ghobrial S, Jeffrey WH (2011) Latitudinal gradients in degradation of marine dissolved organic carbon. PLoS ONE 6:e28900

Arrieta J, Herndl G (2002) Changes in $\beta$-glucosidase diversity during a coastal phytoplankton bloom. Limnol Oceanogr 47:594-599

Baltar F, Arístegui J, Gasol JM, Yokokawa T, Herndl GJ (2013) Bacterial versus archaeal origin of extracellular enzymatic activity in the Northeast Atlantic deep waters. Microb Ecol 65:277-288

Benz R, Bauer K (1988) Permeation of hydrophilic molecules through the outer membrane of gram-negative bacteria. Eur J Biochem 176:1-19

Bong CW, Obayashi Y, Suzuki S (2009) Changes in proteolytic activities in stored seawater and bacterial isolates. In: Obayashi Y, Isobe T, Subramanian A, Suzuki S, Tanabe $\mathrm{S}$ (eds) Interdisciplinary studies on environmental chemistry-environmental research in Asia, Book 2. Terrapub, Ehime, p 287-291

Christian JR, Karl DM (1995) Bacterial ectoenzymes in marine waters: activity ratios and temperature responses in three oceanographic provinces. Limnol Oceanogr 40: 1042-1049

Dixon M, Webb EC (1979) Enzymes. Longman Group, London

Feller G, Gerday C (2003) Psychrophilic enzymes: hot topics in cold adaptation. Nat Rev Microbiol 1:200-208

> Hoppe HG, Kim SJ, Gocke K (1988) Microbial decomposition in aquatic environments: combined process of extracellular enzyme activity and substrate uptake. Appl Environ Microbiol 54:784-790

Hoppe HG, Arnosti C, Herndl G (2002) Ecological significance of bacterial enzymes in the marine environment. In: Burns RG, Dick RP (eds) Enzymes in the environment: activity, ecology and applications. Marcel Dekker, New York, NY, p 73-107

> Huston AL, Deming JW (2002) Relationships between microbial extracellular enzymatic activity and suspended and sinking particulate organic matter: seasonal transformations in the North Water. Deep-Sea Res II 49: 5211-5225

Kellogg C, Carpenter S, Renfro A, Sallon A, Michel C, Cochran J, Deming J (2011) Evidence for microbial attenuation of particle flux in the Amundsen Gulf and Beaufort Sea: elevated hydrolytic enzyme activity on sinking aggregates. Polar Biol 34:2007-2023

Kirchman DL (1993) Leucine incorporation as a measure of biomass production by heterotrophic bacteria. In: Kemp PF, Sherr BF, Sherr BE, Cole JJ (eds) Handbook of methods in aquatic microbial ecology. Lewis Publishers, Washington, DC, p 509-512 
Liu Z, Kobiela ME, McKee GA, Tang T, Lee C, Mulholland MR, Hatcher PG (2010) The effect of chemical structure on the hydrolysis of tetrapeptides along a river-to-ocean transect: AVFA and SWGA. Mar Chem 119:108-120

Obayashi Y, Suzuki S (2005) Proteolytic enzymes in coastal surface seawater: significant activity of endopeptidases and exopeptidases. Limnol Oceanogr 50:722-726

Obayashi Y, Suzuki S (2008a) Adsorption of extracellular proteases in seawater onto filters during size fractionation. J Oceanogr 64:367-372

Obayashi Y, Suzuki S (2008b) Occurrence of exo- and endopeptidases in dissolved and particulate fractions of coastal seawater. Aquat Microb Ecol 50:231-237

Obayashi Y, Ueoka N, Suzuki S (2010) Degradation and utilization of protein derived from Pseudomonas aeruginosa by marine microbial community. J Oceanogr 66: 513-521

Pantoja S, Lee C (1999) Peptide decomposition by extracellular hydrolysis in coastal seawater and salt marsh sediment. Mar Chem 63:273-291

Pantoja S, Lee C, Maracek JF (1997) Hydrolysis of peptides in seawater and sediment. Mar Chem 57:25-40

Pantoja S, Rossel P, Castro R, Cuevas LA, Daneri G, Córdova C (2009) Microbial degradation rates of small peptides and amino acids in the oxygen minimum zone of Chilean coastal waters. Deep-Sea Res II 56:1055-1062

Pomeroy LR, Wiebe WJ (2001) Temperature and substrates

Editorial responsibility: Hans-Georg Hoppe,

Kiel, Germany as interactive limiting factors for marine heterotrophic bacteria. Aquat Microb Ecol 23:187-204

Porter KG, Feig YS (1980) The use of DAPI for identifying and counting aquatic microflora. Limnol Oceanogr 25: 943-948

R Development Core Team (2012) R: a language and environment for statistical computing. R Foundation for Statistical Computing, Vienna. www.R-project.org

Sinsabaugh RL, Hill BH, Follstad Shah JJ (2009) Ecoenzymatic stoichiometry of microbial organic nutrient acquisition in soil and sediment. Nature 462:795-798

Smith DC, Simon M, Alldredge AL, Azam F (1992) Intense hydrolytic enzyme activity on marine aggregates and implications for rapid particle dissolution. Nature 359: 139-142

Steen AD, Arnosti C (2011) Long lifetimes of $\beta$-glucosidase, leucine aminopeptidase and phosphatase in Arctic seawater. Mar Chem 123:127-132

Teske A, Durbin A, Ziervogel K, Cox C, Arnosti C (2011) Microbial community composition and function in permanently cold seawater and sediments from an Arctic fjord of Svalbard. Appl Environ Microbiol 77:2008-2018

Zaccone R, Boldrin A, Caruso G, La Ferla R and others (2012) Enzymatic activities and prokaryotic abundance in relation to organic matter along a West-East Mediterranean Transect (TRANSMED Cruise). Microb Ecol 64: $54-66$

Submitted: March 30, 2012; Accepted: March 5, 2013 Proofs received from author(s): April 17, 2013 